\title{
Varejo responsável
}

Coletânea investiga teórica e empiricamente 0 tema da responsabilidade social no varejo no país e propõe que as empresas têm nas mãos não só oportunidade de ampliar seus negócios mas também compromisso com questões ambientais e humanas mais abrangentes.

\section{por Roberta de Carvalho Cardoso FGV-EAESP}

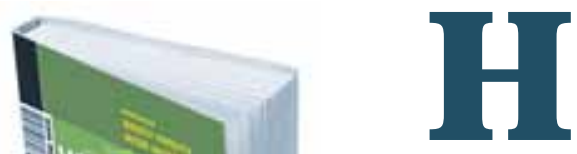

oje não restam dúvidas sobre a importância e a necessidade de as empresas reverem seu papel em questões que refletem sua relação com as comunidades e com a sociedade em geral. Os compromissos econômico-financeiros com os acionistas, que antes eram absolutos, agora são considerados somente como uma parte de um conjunto de responsabilidades da empresa.

Refletindo sensibilidade para essas questões, o livro organizado pelos professores Juracy G. Parente e Jacob Jacques Gelman faz ampla apreciação do estado-da-arte da responsabilidade social no varejo brasileiro. A obra está organizada em três partes e demonstra ter alcançado um balanço equilibrado entre elementos conceituais e experiências reais de empresas.

A primeira parte da obra é formada por uma coletânea de seis artigos de diversos autores, tendo como principal meta a discussão de conceitos e estratégias para a inserção da responsabilidade social na gestão das empresas varejistas. 0 capítulo introdutório, desenvolvido por uma equipe de pesquisadores e professores do GVcev (Centro de Excelência em Varejo) da Fundação Getulio Vargas, reflete o conhecimento acumulado pelo trabalho realizado, nos últimos quatro anos, com empresas e entidades varejistas na área de responsabilidade social.

Com base na lógica sistêmica, os autores resgatam a simbiose existente entre as empresas e o meio em que estão inseridas, o que justifica sua crescente sensibilização às práticas de responsabilidade social. M ais do que uma nova atribuição, o posicionamento social mente responsável da empresa é aqui apresentado como uma forma de vantagem competitiva em relação ao mercado. Além dessa oportunidade, os autores sinalizam que o varejo, devido às suas peculiaridades, tem uma vocação especial para a prática da responsabilidade social.

O capítulo seguinte explora o principal stakeholder de qualquer empreendimento: o consumidor. Com base em sua experiência no Instituto Akatu, o autor descreve o perfil do consumidor consciente e apresenta novas ferramentas de mensuração desse novo consumidor - seja ele pessoa física ou jurídica. 
Este capítulo éindicado aos varejistas que querem conhecer melhor quem é esse novo consumidor e quais as características necessárias para o sucesso do seu negócio nesse novo cenário.

No capítulo três, há uma mudança na abordagem. Enquanto os textos precedentes visualizam a empresa varejista de maneira isolada, este resgata a importância das associações e alianças entre varejistas para a busca de objetivos comuns - no caso, a criação de um ambiente concorrencial ético.

A mesmalinha éexplorada pelos autores do capítulo quatro, que trata da parceria de empresas com organizações da sociedade civil (OSC), demonstrando que esta se dá em estágios distintos que culminam com o alinhamento dos esforços sociais da empresa à sua estratégia competitiva. A leitura deste capítulo permite compreender as diferenças entre os diversos exemplos de práticas de responsabilidade social, fornecendo elementos para que o leitor possa escolher e programar, de maneira mais adequada, as ações de sua empresa.

Ao final da Parte I, o leitor encontra um estudo em profundidade sobre as ações de responsabilidade social desenvolvidas por 160 empresas que participaram das duas edições do Prêmio FGVEAESP de Responsabilidade Social no Varejo.

A Parte II apresenta os 20 casos de responsabilidade social adotados por empresas ou associações varejistas que foram finalistas e vencedoras do $2^{\circ}$ Prêmio FGV-EAESP de Responsabilidade Social no Varejo, realizado em 2004. Os casos evidenciam a grande variação nas iniciativas que estão associadas não só ao porte das empresas mas também aos estágios de atuação, aos stakeholders envolvidos e ao volume de recursos destinados às ações. Por fim, a última parte do livro é dedicada à revisão da evolução dos conceitos de responsabilidade social empresarial e à elaboração de uma síntese dos casos brasileiros.

A leitura deste livro é recomendada para empresários e executivos, especialmente de empresas varejistas, interessados em adotar uma filosofia mais avançada de gestão que contemple não apenas resultados de curto prazo, mas que estejam comprometidos com o seu papel social, sua sobrevivência e sustentabilidade no longo prazo.

\section{Roberta de Canvalho Cardoso}

Doutora em Administração pela FGV-EAESP Pesquisadora do GVcev - Centro de Excelência em Varejo

E-mail: rcc@fgvsp.br

\section{- A pesar da grande aceitação retórica da responsabilidade social como algo necessário e desejável para as organizações, estas ainda encontram muita dificuldade na operacionalização desse conceito que, muitas vezes, permanece restrito a ações pontuais.}

